\title{
Estimating Hydraulic Properties of Alluvial Sand Aquifer in Motloutse River course, Eastern Botswana
}

\section{Edwin OK \\ Alemaw BF ${ }^{2}$ \\ Laletsang $\mathrm{K}^{3}$ \\ Tafesse NT $^{4}$}

'Aqualogic (pty) Ltd, Gaborone, Botswana,

2,s, Department of Geology, University of Botswana, Gaborone, Botswana

Emailed acinkeaitse @ valoo.com

Email:LALETSAK@mopipinb.bwe Teli: +267355259

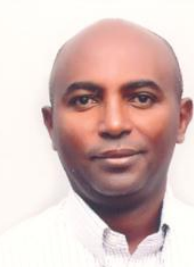

Corresponding Author)

\begin{abstract}
A single layered alluvial aquifer in Botswana along the Motloutse River catchment was studied to estimate its hydraulic properties. Ground Penetrating Radar Survey (GPR) was used to determine the thickness and porosity of the aquifer. Specific yield of the aquifer was determined in the laboratory. The hydraulic conductivity of the riverbed sediments were estimated using the Alyamani-Sen empirical formula and the hydraulic conductivity of the river bank sediment was measured using the slug test. Geologically, the area is consists of alluvial deposits overlying granite, which is the bed rock of the area. The geophysical survey, GPR, provided information on the range of the thickness of the alluvium $(9-12 \mathrm{~m})$ and also the porosity of the sediments $(40 \%)$. The laboratory test resulted in an average specific yield of $13.68 \%$ for the riverbed sediments and $8.84 \%$ for the river bank sediments. A slug test performed in the riverbank yielded estimates of hydraulic conductivity of $26.43 \mathrm{~m} /$ day. An average hydraulic conductivity value of $160 \mathrm{~m} /$ day for the riverbed sediments was determined using the Alyamani-Sen formula. This difference in the hydraulic properties of the riverbed and the riverbank sediments is likely to be a result of sediment heterogeneity as more fine grained sediments is found together with sand in the riverbank sediments. These combined hydraulic properties estimation using empirical formulas, geophysical survey, laboratory tests, and the slug test highly improved the understanding of the hydrologic properties of the single layered alluvial aquifer system in the Motloutse River catchment. In the same area, groundwater resource modelling can be done using these aquifer parameters to determine the groundwater potential of the aquifer.
\end{abstract}

Keywords: Alluvial aquifer, Botswana, Groundwater, Hydraulic properties, Motloutse River.

Citation | Edwin OK; Alemaw BF; Laletsang K; Tafesse NT (2017). Estimating Hydraulic Properties of Alluvial Sand Aquifer in Motloutse River course, Eastern Botswana. Asian Review of Environmental and Earth Sciences, 4(1): 28-35.

History:

Received: 2 October 2017

Revised: 6 December 2017

Accepted: 11 December 2017

Published: 14 December 2017

Licensed: This work is licensed under a Creative Commons

Attribution 3.0 License (cc)

Publisher:Asian Online Journal Publishing Group
Contribution/Acknowledgement: All authors contributed to the conception and design of the study.

Funding: The research work presented in this paper is sponsored by the University of Botswana through Office of Research and Development (ORD). Authors highly appreciate the financial assistance.

Competing Interests: The authors declare that they have no conflict of interests.

Transparency: The authors confirm that the manuscript is an honest, accurate, and transparent account of the study was reported; that no vital features of the study have been omitted; and that any discrepancies from the study as planned have been explained.

Ethical: This study follows all ethical practices during writing.

\section{Contents}

1. Introduction

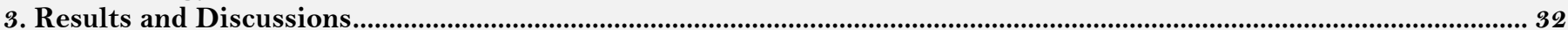

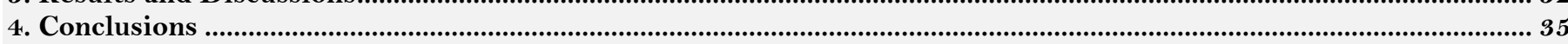

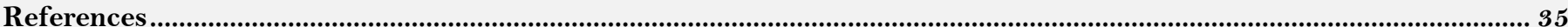




\section{Introduction}

\subsection{General}

Botswana is a semi-arid country with subdued topography, low surface runoff, and low groundwater recharge [1]. Rural communities in Botswana rely on agriculture for income, food and employment. The farming activity is sustained with rain-fed agriculture, which is affected by harsh climatic conditions. However, in eastern Botswana, ephemeral sand rivers constitute a large source of groundwater $[1,2]$ which may be useful for irrigation. Rainfall over the Motloutse catchment area occurs in summer, and mean monthly evaporation exceeds mean monthly rainfall. Communities within the river catchment depend on the river to sustain their agricultural needs.

The geology of the area is consists of alluvial deposits overlying the granite, which is the bed rock of the area. The alluvial deposits or the Motloutse sand river consists mainly of sand and gravel at variable depth, with coarse sand along the middle of the river and silt and clay occurring adjacent to river banks. The alluvial sediments in the flood plain are a source of water for the different needs of the community during the dry months. The aquifer is unconfined and receives recharge from the river flow and direct percolation.

The hydrogeological characteristics of the Motloutse alluvial aquifers are not documented [3] and effective water management, water storage planning and management are hampered by the lack of knowledge of their storage properties. This complicated by the varying thickness of the river sand, river morphology, and the increasing demand from the community. Groundwater potential of the Motloutse alluvial aquifer was investigated to support irrigation development and to improve the livelihoods of the communal farmers. The main objective of this work was to determine the different hydraulic properties of the Motloutse alluvial aquifer on a one kilometre stretch of the Motloutse River that can be used to quantify the groundwater resource potential in the area.

\subsection{Location}

The study area is located in eastern Botswana near the Mmadinare, Tobane and Bobonong villages (Figure 1). It lays along the Motloutse River, downstream of the Letsibogo dam in the Motloutse catchment, a sub-catchment of the Limpopo basin. Four countries in south-eastern Africa share the Limpopo basin: Botswana, Mozambique, South Africa and Zimbabwe.

The majority of the Motloutse catchment is characterised by flat savannah and, although devoid of major mountains, few hills are present in the catchment. It is $\sim 20,000 \mathrm{~km}^{2}$ in area and the Motloutse river has a stream length of $\sim 250 \mathrm{~km}$ in an east-west trend with the tributaries trending north-south ( Figure 1). The main land use is subsistence farming with vast areas of land used as grazing growing crops.

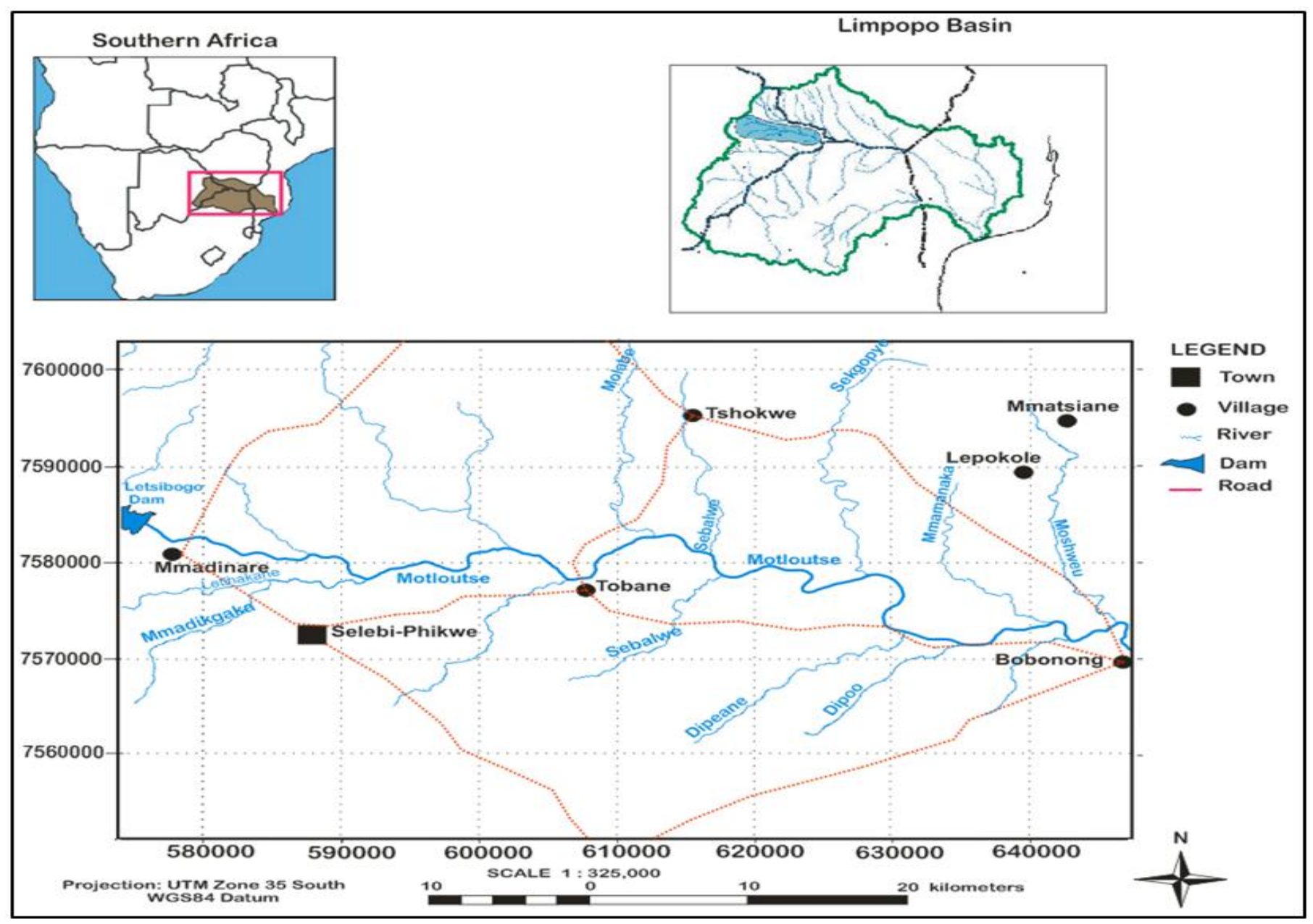

Figure-1. Location map of study area within Southern Africa and Limpopo basin.

Source: Edwin O.K., M.Sc. thesis, University of Botswana, Gaborone, Botswana, 2016.

\section{Methodology}

Ground Penetrating Radar (GPR) was used to map the depth to bedrock across the Motloutse River, and indirectly the thickness of the sand within the channel.

Ground Penetrating Radar (GPR) is a geophysical method used to detect and map shallow subsurface features with high precision. It is similar in many respects to seismic reflection and refraction methods but it utilizes electromagnetic waves to reflect, refract, and diffract from subsurface targets instead of acoustic waves. 
The choice of location for the GPR profiles was based on the width, access, and slope of the riverbed. Five (5) radar transacts across the Motloutse river were recorded near Tobane village (Figure 2). These profiles were trending north-south and their length was determined by the river width ranging between 100 and $135 \mathrm{~m}$. These transacts were spaced at $250 \mathrm{~m}$ as illustrated in Figure 2. Along each of these profiles, elevations and coordinates were captured with Trimble Differential Global Positioning System (DGPS) from the two (2) banks and along the middle section of the river for topographic corrections. The radar grid was confined to the channel width and not extended to the alluvial plains due to riverine vegetation that impedes access. Optimum offset GPR reflection profiles were recorded along the profiles using a $50 \mathrm{MHz}$ Ramac ${ }^{\mathrm{TM}}-$ Mala Geoscience ${ }^{\mathrm{TM}} \mathrm{GPR}$ system with unshielded antennae. The antennae's were kept at a constant separation of $2 \mathrm{~m}$ with a wooden raft. The antennas were orientated parallel to each other and perpendicular to the profile. To improve the signal to noise ratio every trace was vertically stacked sixteen (16) times. A hip chain with a bio-degradable thread was used to measure the profile length. The velocity of the profiles was recorded directly from the display device at $59 \mathrm{~m} / \mu \mathrm{s}$. This value was be used to calibrate the processing software packages so that correct depths are determined.

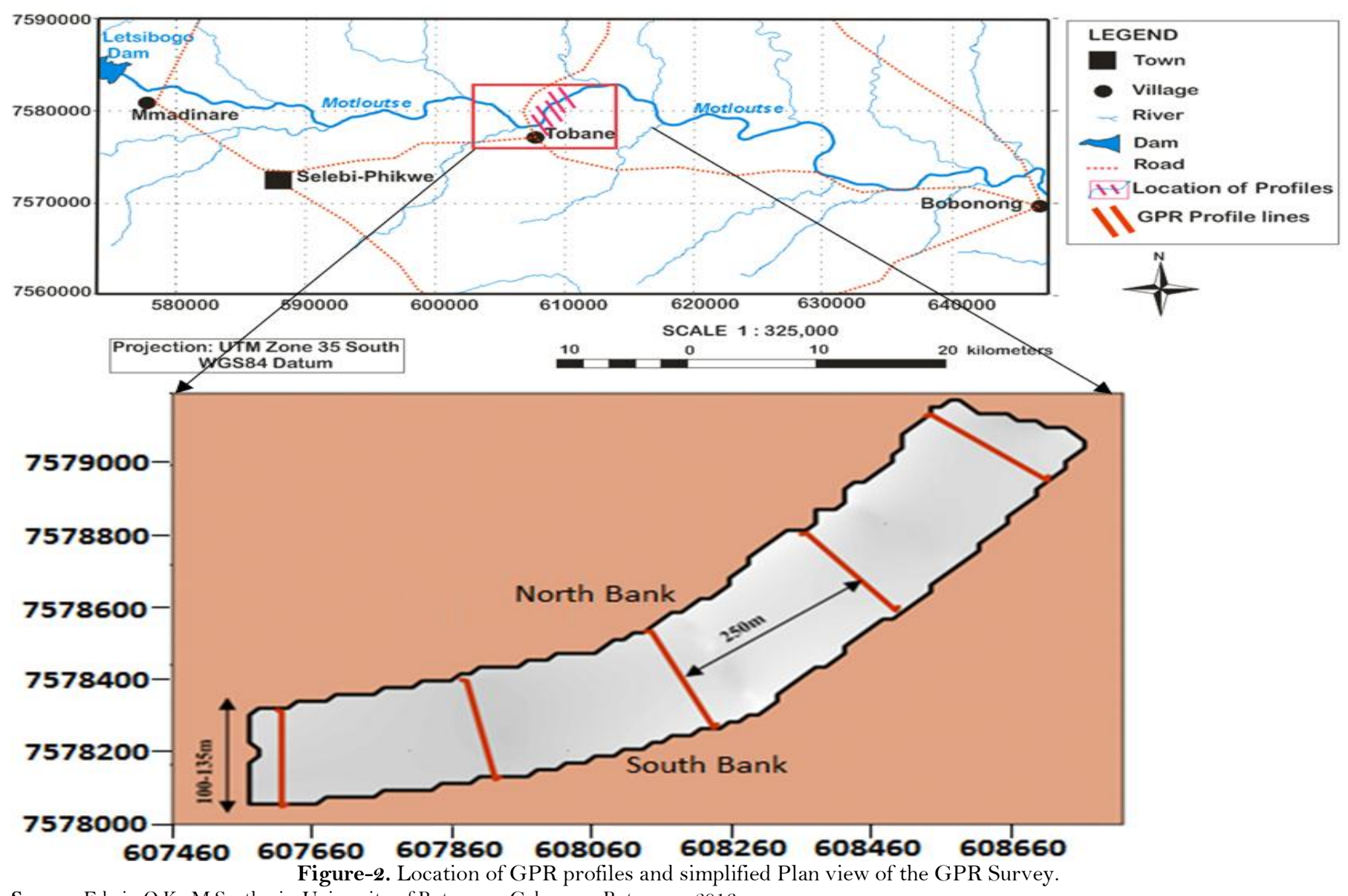

Source: Edwin O.K., M.Sc. thesis, University of Botswana, Gaborone, Botswana, 2016.

Apart from the basic detection and mapping of subsurface geological features, GPR measurements can also be used to determine hydraulic properties of porous materials such as porosity, hydraulic conductivity, water saturation, etc. as has been shown in numerous previous investigations [4-9]. This is because related parameters such as dielectric constant and radar wave velocity are highly dependent on moisture content. In low loss medium (soils with low salinity and clay content) which is expected of river sand, the velocity (V) of the soil can be related to the dielectric constant by Eq. 1 [10].

$$
V=\frac{c}{\sqrt{K^{\prime}}}
$$

Where $\mathrm{c}$ is the electromagnetic wave velocity in free space, and $K^{\prime}$ is the real part of the dielectric constant of the medium.

Velocity of $0.06 \mathrm{~m} / \mathrm{ns}$ that was read from the Ramac Mala Geoscience display device which is also in conjunction with velocity for unsaturated sands was used and dielectric constants read from tables of dielectric constants for different materials [10,11]. Topp, et al. [7] using various soil samples found out that the real part of the dielectric constant was increasingly sensitive to volumetric water content, while also weakly sensitive to soil type and density and derived an empirical relationship (Eq. 2) between apparent dielectric constant and volumetric water content:

$$
\theta_{v}=-5.3 \times 10^{-2}+2.92 \times 10^{-2} K_{a}-5.5 \times 10^{-4} K_{a}^{2}+4.3 \times 10^{-6} K_{a}^{3}
$$

Where $\theta_{v}$ is the volumetric water content (the ratio of water volume to total sample volume). For low-loss materials $\mathrm{Ka} \approx \mathrm{K}^{\prime}$ where Ka is the apparent dielectric constant and $\mathrm{K}^{\prime}$ is the real part of the dielectric constant of the medium as it was defined in Eq. 1.

The water content $\left(\theta_{v}\right)$ equals the product of porosity $(\varnothing)$ and water saturation $\left(S_{w}\right)$ as in Eq. $3[5]$. $\theta_{v}=\varnothing S_{w}$

Where water saturation $\left(\boldsymbol{S}_{\boldsymbol{w}}\right)$ is the ratio of water volume to pore volume.

However in water saturated soils the water content $\left(\theta_{v}\right)$ is a measure of porosity $(\varnothing)$, that is, $\theta_{v} \approx \emptyset$.

After ground penetrating radar survey, as a ground-truth control the Motloutse River was augered at the sites where GPR data was collected. The riverbed was augered to a depth of $3.5 \mathrm{~m}$ and the water was striked at a depth of $0.6 \mathrm{~m}$. Augering to a further depth was not possible because the auger tool itself nearly got damaged, any further 
twist it would have broken. It was initially a pit was dug to a depth of about $2 \mathrm{~m}$ using shovels and from there the auger was installed but the water that was collected in the pit was too much and hindered the augering process.3.5 $\mathrm{m}$ is not the exact thickness; the sand is much thicker than this amount. However, the thickness of sand is not uniform throughout the area where this measurement was conducted; the riverbed in some areas had deeper sand thicknesses and the augering was done in areas were the sand is thinner.

The specific yield of the sandy aquifer was determined in the Engineering Geology laboratory of the Department of Geology in the University of Botswana. Specific yield is the ratio of water that can be drained by gravity from a saturated sample to the total volume of sediment in laboratory terms. Freeze and Cherry [12] defined it as the amount of water released from storage of an unconfined aquifer per unit surface area of the aquifer per unit decline of the water table. Specific yield is given by Eq. 4 after Meinzer [13].

$$
S_{y}=\frac{V_{d}}{V_{t}}
$$

Where Sy is specific yield, $\mathrm{V}_{\mathrm{d}}$ is volume drained from aquifer by gravity; and, $\mathrm{V}_{\mathrm{t}}$ is total volume.

Nine sand samples representative of the aquifer material were collected both from the riverbed and at the riverbanks for this purpose. Out of these samples 5 of them were from the riverbed and the remaining four were from the riverbank (Figure 3). Samples were obtained from a depth of 2 and $3 \mathrm{~m}$ on the aquifer to avoid surface sampling, this is due to some physical and biological processes such as surface shrinkage, silty layers or lenses referred to as "planosols" that result in varying aquifer properties [14].

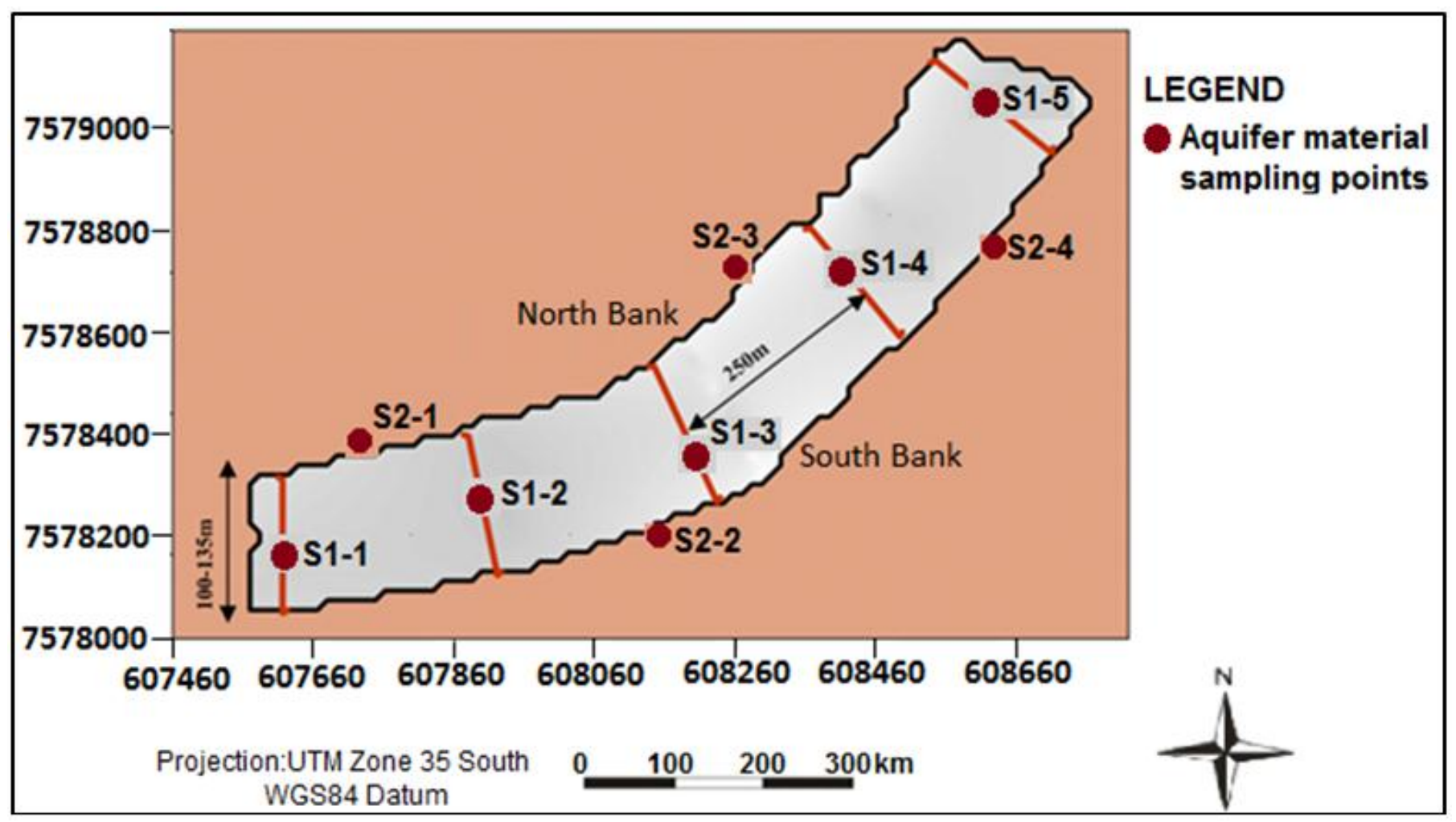

Figure-3. Location of aquifer material sampling sites in relation to GPR profiles.

Source: Edwin O.K., M.Sc. thesis, University of Botswana, Gaborone, Botswana, 2016.

The hydraulic conductivity of the sediments was determined using an empirical formula and the slug-test method.

For the riverbed, the hydraulic conductivity of the sandy aquifer was determined by empirical formula using the collected riverbed samples. The method used in this study is the Alyamani-Senempirical formula, which is given by Alyamani and Sen [15] as

$$
K=1300\left[I_{o}+0.025\left(d_{50}-d_{10}\right)\right]^{2}
$$

Where $\mathrm{K}$ is hydraulic conductivity ( $\mathrm{m} /$ day), $\mathrm{I}_{0}$ is intercept (in $\mathrm{mm}$ ) of the line formed by $\mathrm{d}_{50}$ and $\mathrm{d}_{10}$ with the grain-size axis, or simply the $\mathrm{x}$-axis, $\mathrm{d}_{50}$ is median grain diameter $(\mathrm{mm})$, and, $\mathrm{d}_{10}$ is effective grain diameter $(\mathrm{mm})$.

The Alyamani and Sen [15] formula was chosen because the equation considers both sediment grain sizes as well as the sorting characteristics.

Grain size analysis of the sediment was done in accordance to the ASTM D-422 or D2487 standard (American Society for Testing and Materials) and Unified Soil Classification System (USCS) as both are the most widely used technical standards.

To determine the hydraulic conductivity of the riverbank sediments an in situ measurement was carried out using Slug test. The test was carried out as follows.

- A one metre PVC tube was pressed vertically into the aquifer until the slots in the tube were submerged under the water level;

- The tube was submerged up to $24 \mathrm{~cm}$ under the water level with $76 \mathrm{~cm}$ remaining over the water table;

- Sufficient water was then poured into the tube until it reached top of the tube and this is to ensure the saturation of a large area of the aquifer around and below place of measurement; and,

- Time taken for the head to fall or attain initial water level was recorded.

$\mathrm{K}$ from Slug test was estimated using Eq. 6 after Masvopo, et al. [16] as follows;

$$
K=\frac{Q}{A_{i}}=\frac{\left[\pi R^{2} h\right]}{T\left[2 \pi R H+\pi R^{2}\right]}
$$


Where $\mathrm{K}$ is hydraulic conductivity ( $\mathrm{m} /$ day), $\mathrm{Q}$ is discharge ( $\mathrm{m}^{3} /$ day), A is cross sectional area of soil sample $\left(\mathrm{m}^{2}\right)$, $\mathrm{i}$ is hydraulic gradient, $\mathrm{R}$ is radius of tube $(\mathrm{m})$, $\mathrm{T}$ is time taken for water column to attain initial water level (day), and, $\mathrm{H}$ is length of PVC tube under the water level $(\mathrm{m})$.

\section{Results and Discussions}

\subsection{Geophysics}

Even though five radar transacts were recorded and analyzed only two of them are presented here for the purpose of discussion. This radar transacts were the one that was recorded at the beginning (Figure 4) and in the end (Figure 5) of the measurements; recorded in the downstream and upstream side of the river, respectively, or at the site from where the soil samples $S_{1-1}$ and $S_{1-5}$ (Figure 3) were collected. These figures show both the raw radar images (Figure 4A and Figure 5A) and the migrated radar images (Figure 4B and Figure 5B) in these sites. In the Figure $4 \mathrm{~B}$ the migration was accomplished using a DC permitivity value of 65 (dielectric constant) whereas in Figure $5 \mathrm{~B}$ migration was done with a dielectric constant of 70 .

The first reflections in all the figures are a characteristic airwave and groundwave, respectively. This is caused by the direct electromagnetic wave interaction with air, and is represented by black, continuous reflection amplitudes that form a very straight, horizontal solid bar as on in Figure 4A and 5A. Below the groundwave reflection is the unsaturated zone of the sediment, interpreted as the unsaturated sand.

The next two or three prominent (three in Figure 4A and 2 in Figure 5A), high amplitude reflections that are easily identified and traced across all the radar records are interpreted as the water table. This is because in sediments, the water content primarily causes the changes in dielectric properties [17]. A change from dry to wet sand results in a change from a three- phase system (air, water and sediment) to a two- phase system (water and sediment) in which other factors apart from porosity control the dielectric properties [18].

Further down the profile after the water table, the next reflections are generally weak in all the radargrams (Figure 4A and Figure 5A) but follow a similar trend to it. Since attenuation is strong below this point this could be indicative of groundwater. Conyers [19] affirms that the water content often increases with depth resulting in attenuation of radar waves with increasing depth. These stronger groundwater reflectors could be related to sediments that have a larger sand fraction at depths: suggesting to be bounding surfaces between two sand layers of different periods of deposition.

Below these reflections, no further reflections are observed in wiggle form in all radargrams; suggesting a marked change in reflective characteristics. This is interpreted as an interface between the sediments and the bedrock because at the resolution used, radar signals will not be able to penetrate the granite bedrock. However, this not at achieved at the same depth in all the profiles. As shown in Figure 4B on the migrated image that the sand thickness reaches up $12 \mathrm{~m}$ whereas in the upstream side the sand thickness is less and reaches up $9 \mathrm{~m}$ (Figure $5 \mathrm{~B})$.

The GPR results obtained match or corroborate with the augering findings. As earlier noted from augering observation the sand was much thicker than $3.5 \mathrm{~m}$. Based on water strikes the water levels seem to be a bit shallower from those in GPR interpretations because at the time of augering it was already rainy season.
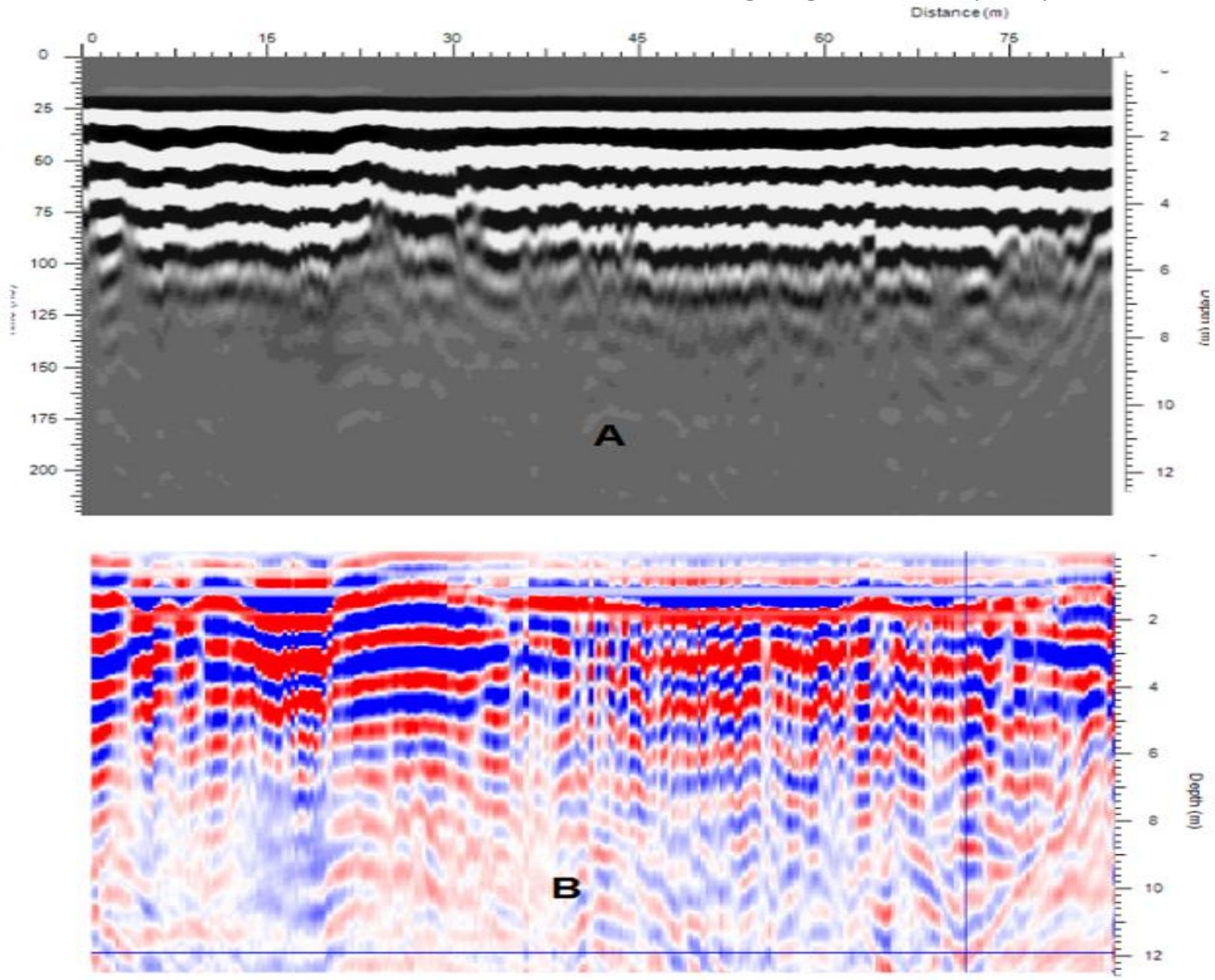

Figure-4. A) The raw radar image before migration; B) The migrated radar image.

Source: Edwin O.K., M.Sc. thesis, University of Botswana, Gaborone, Botswana, 2016. 

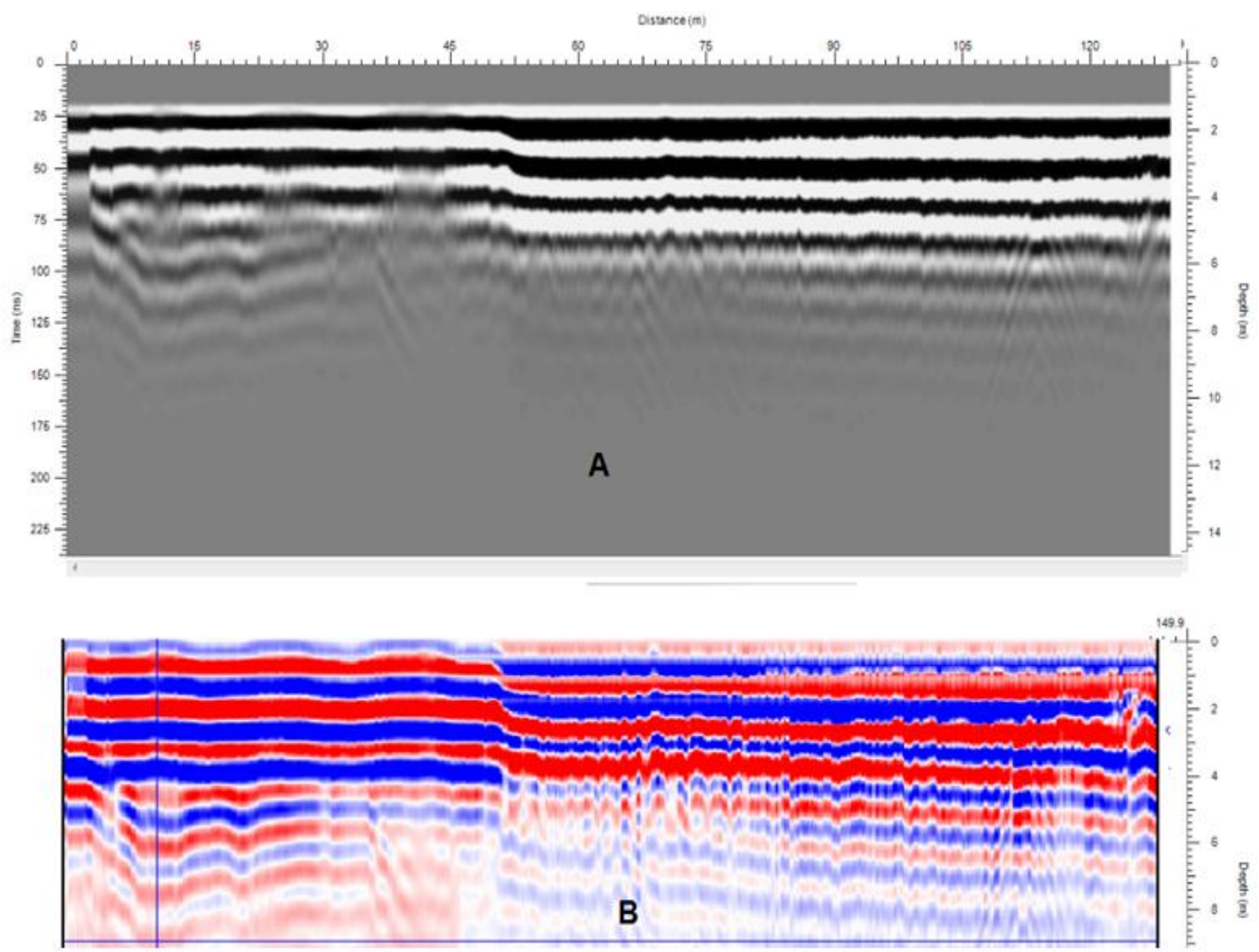

Figure-5. A) The raw radar image before migration; B) The migrated radar image.

Source: Edwin O.K., M.Sc. thesis, University of Botswana, Gaborone, Botswana, 2016.

\subsection{Aquifer Parameters}

\section{Porosity}

Porosity was found to be $40 \%$ determined from the Ground Penetrating Radar. This high porosity value is expected for river sands and for clays and silts from riverbank samples. It is also within the range of values reported in the literature for such materials. Representative porosity values for various unconsolidated sedimentary materials, sedimentary rocks and crystalline reported by Morris and Johnson [20] stated that the range of porosity for coarse sand to clay is from $31 \%$ to $57 \%$. According to Freeze and Cherry [12] the range of porosity values for sand, silt and clay is from $25 \%$ to $70 \%$. Nord [21] obtained a porosity of $35 \%$ for Motloutse River sand.

\section{Specific Yield}

Table-1. Computation of specific yield.

\begin{tabular}{l|l|l|l|l|l|l|l}
\hline Sample ID & $\begin{array}{l}\text { Mass of } \\
\text { beaker + } \\
\text { saturated } \\
\text { sand (g) }\end{array}$ & $\begin{array}{l}\text { Mass of } \\
\text { empty } \\
\text { beaker }(\mathbf{g})\end{array}$ & $\begin{array}{l}\text { Mass of } \\
\text { saturated } \\
\text { sand }(\mathbf{g})\end{array}$ & $\begin{array}{l}\text { Mass } \\
\text { beaker } \\
\text { +drained sand } \\
(\mathbf{g})\end{array}$ & $\begin{array}{l}\text { Mass of } \\
\text { drained } \\
\text { sand }(\mathbf{g})\end{array}$ & $\begin{array}{l}\text { Mass of water } \\
(\mathbf{g})\end{array}$ & $\begin{array}{l}\text { Specific } \\
\text { Yield }\end{array}$ \\
\hline S1-1 & 476.40 & 33.80 & 442.6 & 464.24 & 430.44 & 12.16 & 7.49 \\
\hline S1-2 & 521.07 & 32.65 & 488.42 & 486.65 & 454.00 & 34.42 & 20.09 \\
\hline S1-3 & 494.06 & 32.65 & 461.41 & 460.78 & 428.13 & 33.28 & 20.60 \\
\hline S1-4 & 452.32 & 33.80 & 418.52 & 434.04 & 400.24 & 18.28 & 12.10 \\
\hline S1-5 & 480.35 & 33.80 & 446.55 & 467.05 & 433.25 & 13.3 & 8.14 \\
\hline S2-1 & 527.38 & 32.65 & 494.73 & 501.62 & 468.97 & 25.76 & 14.56 \\
\hline S2-2 & 476.96 & 33.80 & 443.16 & 464.35 & 430.55 & 12.61 & 7.76 \\
\hline S2-3 & 501.43 & 33.80 & 467.63 & 476.25 & 442.45 & 25.18 & 3.69 \\
\hline S2-4 & 485.96 & 32.65 & 453.31 & 455.01 & 422.36 & 30.95 & 7.33 \\
\hline
\end{tabular}

Source: Edwin O.K., M.Sc. thesis, University of Botswana, Gaborone, Botswana, 2016.

Specific gravity of sand was taken as 2.65 because river sand has the main component as quartz and this value is applicable to sands that are not packed. An average specific yield of $13.68 \%$ for samples collected only on the riverbed was found (Table 1), which is low for this river section as compared to that derived by Nord [21] of $20 \%$ and very low for a typical sand formation which has a range of 21 to $27 \%$ [22]. An average specific yield for the river bank sediments is much lower than the riverbed one. However, both these values will give a conservative estimate of the groundwater resource.

\section{Hydraulic Conductivity}

In the analysed sediment samples, the grain size ranges from $0.008 \mathrm{~mm}$ to $10 \mathrm{~mm}$ in diameter as can be seen in Figure 6, which is a very wide range attesting to the poorly graded sand and the heterogeneous nature of the 
aquifer. The median $\left(\mathrm{d}_{50}\right)$ and effective grain diameter $\left(\mathrm{d}_{10}\right)$ are 1.6 and 0.4 , respectively. According to the Unified Soil Classification System [22] the Motloutse sediment is poorly graded sand with gravel or gravelly sand.

Table-2. USCS classification of aquifer material samples.

\begin{tabular}{l|l|l|l|l|l}
\hline Sample ID & S1-1 & S1-2 & S1-3 & S1-4 & S1-5 \\
\hline Per cent fines & 0.14 & 0.1 & 0.1 & 0.3 & 0.2 \\
\hline Per cent sand & 95.8 & 81.8 & 79.1 & 97.3 & 81.1 \\
\hline Per cent gravel & 3 & 7.7 & 16.3 & 1.4 & 18.7 \\
\hline $\mathrm{C}_{\mathrm{c}}$ & 1.16 & 0.89 & 0.98 & 0.89 & 0.88 \\
\hline $\mathrm{C}_{\mathrm{u}}$ & 3.2 & 4.5 & 4.7 & 3.2 & 4.3 \\
\hline USCS classification & SP & SP & SP & SP & SP \\
\hline Source: Edwin O.K., M.Sc. thesis, University of Botswana, Gaborone, Botswana, 2016.
\end{tabular}

Where $\mathrm{C}_{\mathrm{c}}$ is coefficient of curvature; $\mathrm{C}_{\mathrm{u}}$ is coefficient of uniformity; and, SP is poorly graded sand. Coefficient of curvature, $C c$, is the ratio $\left(D_{30}\right)^{2} /\left(D_{10} \times D_{60}\right)$, where $D_{60}, D_{30}$, and $D_{10}$ are the particle sizes corresponding to 60,30 , and $10 \%$ finer on the cumulative particle-size distribution curve, respectively.

Coefficient of uniformity, $\mathrm{Cu}$, is the ratio $\mathrm{D}_{60} / \mathrm{D}_{10}$, where $\mathrm{D}_{60}$ and $\mathrm{D}_{10}$ are the particle diameters corresponding to 60 and $10 \%$ finer on the cumulative particle-size distribution curve, respectively.

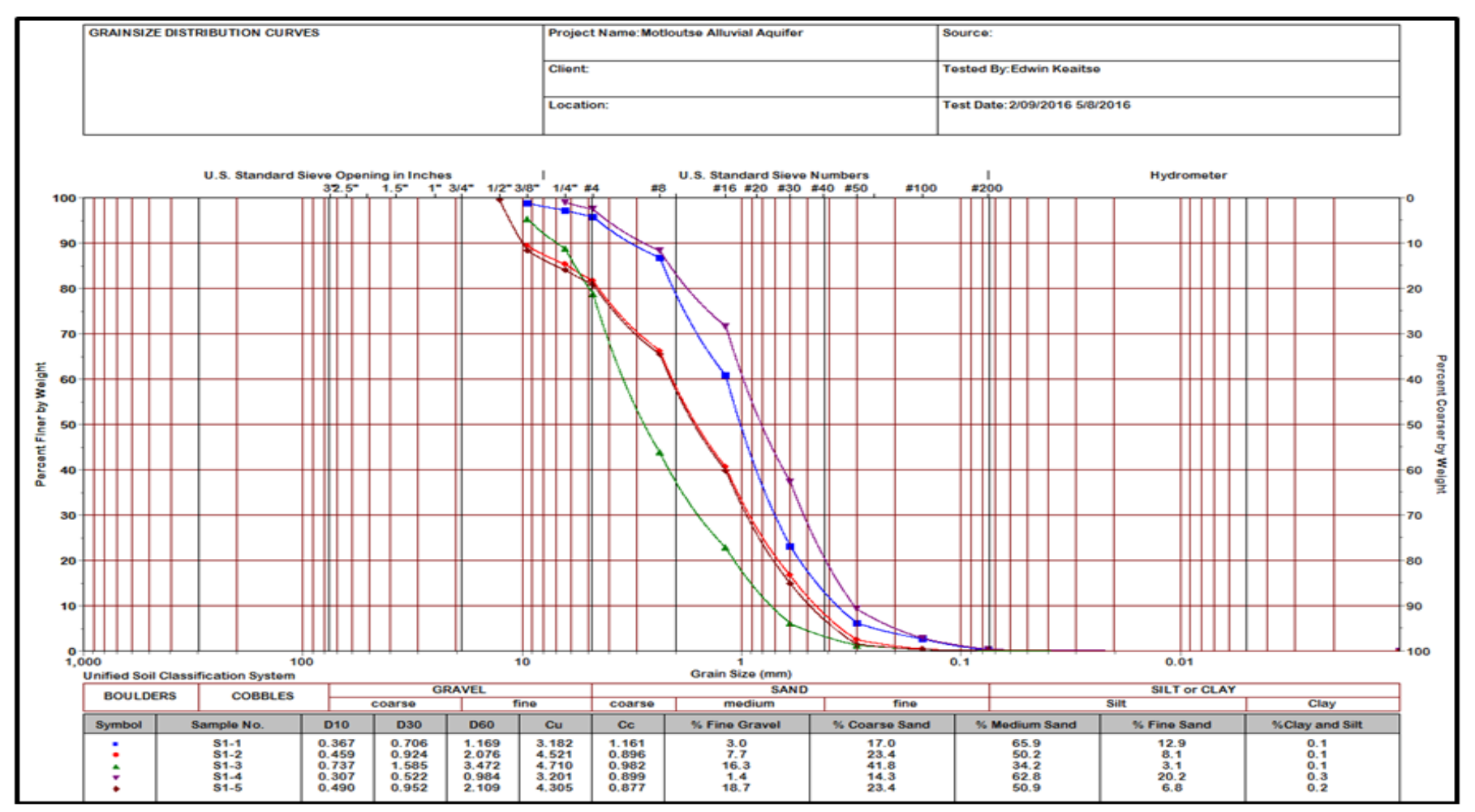

Figure-6. Grain size distribution curve of the Motloutse sediments.

Source: Edwin O.K., M.Sc. thesis, University of Botswana, Gaborone, Botswana, 2016.

Hydraulic conductivity using Alyamani-Sen formula

Table-3. Computed hydraulic conductivity values using Alyamani-Sen formula.

\begin{tabular}{|c|c|c|c|c|c|c|c|}
\hline Sample ID & $\mathbf{d}_{10}$ & $\mathbf{d}_{s o}$ & $\mathbf{d}_{60}$ & $\mathbf{C}_{\mathrm{u}}$ & $\mathbf{C}_{\mathrm{c}}$ & Io & Hydraulic conductivity (m/day) \\
\hline $\mathrm{S} 1-1$ & 0.3 & 0.7 & 1.1 & 3.2 & 1.1 & 0.3 & 113.9 \\
\hline S1-2 & 0.4 & 0.9 & 2.1 & 4.5 & 0.9 & 0.3 & 144.8 \\
\hline S1-3 & 0.7 & 1.6 & 3.4 & 4.7 & 0.9 & 0.5 & 443.1 \\
\hline $\mathrm{S} 1-4$ & 0.3 & 0.5 & 0.9 & 3.2 & 0.8 & 0.3 & 89.6 \\
\hline $\mathrm{S} 1-5$ & 0.4 & 0.9 & 2.1 & 4.3 & 0.8 & 0.3 & 161.9 \\
\hline \multicolumn{8}{|l|}{$\mathrm{K}$ mean $=160.4$} \\
\hline
\end{tabular}

An average hydraulic conductivity value of $160 \mathrm{~m} /$ day $\left(1.856 \times 10^{-3} \mathrm{~m} / \mathrm{sec}\right)$ for gravelly sand was determined using Alyamani-Sen formula. This value is within a reasonable range of values of hydraulic conductivity for gravelly sand. Representative values of hydraulic conductivity for various unconsolidated sedimentary materials, sedimentary rocks, igneous and metamorphic rocks complied by Freeze and Cherry [12] shows that the values of hydraulic conductivity for gravelly sand is ranging from $1.157 \times 10^{-4}$ to $1.157 \times 10^{-1} \mathrm{~m} / \mathrm{sec}$.

Hydraulic conductivity from Slug test

Table-4. Hydraulic conductivity from Slug test.

\begin{tabular}{l|l|l|l|l|l|l}
\hline Sample ID & Radius $(\mathbf{m})$ & $\mathbf{h}(\mathbf{m})$ & $\mathbf{T}(\mathbf{s})$ & $\mathbf{H}(\mathbf{m}) \mathbf{2}$ & $\mathbf{K}(\mathbf{m} / \mathbf{s})$ & $\mathbf{K}(\mathbf{m} / \mathbf{d})$ \\
\hline S2-1 & 0.01 & 0.76 & 29 & 0.24 & 0.000166776 & 14.40947992 \\
\hline S2-2 & 0.01 & 0.76 & 2000 & 0.24 & 0.000378298 & 32.68491787 \\
\hline S2-3 & 0.01 & 0.76 & 3500 & 0.24 & 0.000534835 & 46.20971147 \\
\hline S2-4 & 0.01 & 0.76 & 6000 & 0.24 & 0.000143613 & 12.40816327 \\
\hline K mean & \multicolumn{7}{|l}{} & & $\mathbf{2 6 . 4 3}$ \\
\hline
\end{tabular}


Slug test produced a mean value of $26.43 \mathrm{~m} /$ day $\left(3.059 \times 10^{-4} \mathrm{~m} / \mathrm{sec}\right)$ for the riverbank sediments. This value is also within a reasonable range of values of hydraulic conductivity for sand that comprises of a lot of silt and clay.

\section{Conclusions}

A one-layered aquifer, riverbank alluvial and riverbed deposits, was studied to characterize their hydraulic properties. Geologically the area is consisting of alluvial deposits overlying the granite, which is the bed rock of the area. The alluvial deposits or the Motloutse sand river consists mainly of sand and gravel at variable depth, with coarse sand along the middle of the river and silt and clay banks occurring adjacent to river banks. Geophysics method have been applied to resolve depth to bedrock using GPR, and it is found that the range of the thickness of the alluvium varies from $9-12 \mathrm{~m}$, and GPR also provided reasonable estimates of porosity of the sediments, which is $40 \%$.

The grain size analyses of the riverbed sediments revealed that the Motloutse sediments are poorly graded gravelly sand. The laboratory test resulted in an average specific yield of $13.68 \%$ for the riverbed sediments and $8.84 \%$ for the river bank sediments. A slug test performed in the riverbank yielded estimates of hydraulic conductivity of $26.43 \mathrm{~m} /$ day $\left(3.059 \times 10^{-4} \mathrm{~m} / \mathrm{sec}\right)$. An average hydraulic conductivity value of $160 \mathrm{~m} /$ day $\left(1.856 \times 10^{-}\right.$ ${ }^{3} \mathrm{~m} / \mathrm{sec}$ ) for gravelly sand was determined using Alyamani-Sen formula.

This difference in hydraulic properties of the riverbed sediments and the riverbank sediments is likely a result of sediment heterogeneity as more fine grain sediments are found together with sand in the riverbank sediments.

These combined hydraulic properties estimation using empirical formula, geophysical survey, laboratory test and slug test greatly enhanced the understanding of the hydrologic properties of the single layered alluvial aquifer system in the Motloutse River catchment. For those who want to continue further studies in the studied area, these determined aquifer parameters can be used to determine the groundwater potential of the aquifer using groundwater modeling techniques.

\section{References}

[1] Government of Botswana National Water Master Plan Review, "Gaborone, Ministry of Mineral, Energy \& Water Resources, Department of water affairs," vol. 4, p. 30, 2006.

[2] R. Herbert, J. Barker, J. Davies, and O. Katai, "Exploiting groundwater from sand rivers in Botswana using collector wells," in Proc. 30th /International Geology Congress, 1997, pp. 235-257.

[3] D. Love, W. Hamer De, R. Owen, M. Booij, S. Uhlenbrook, A. Hoekstra, and P. Zaag Van Der, "Case studies of groundwater: Surface water interactions and scale relationships in small alluvial aquifers," presented at the 8th WaterNet/WARFSA/GWP-SA Annual Symposium, Lusaka, Zambia, 2007.

[4] J. A. Huisman, C. Sperl, W. Bouten, and J. M. Verstraten, "Soil water content measurements at different scales: Accuracy of time domain reflectometry and ground-penetrating radar," Journal of Hydrology, vol. 245, pp. 48- 58, 2001. View at Google Scholar | View at Publisher

[5] A. Turesson, "Water content and porosity estimated from ground-penetrating radar and resistivity," Journal of Applied Geophysics, vol. 58, pp. 99-111, 2006. View at Google Scholar | View at Publisher

[6] J. A. Doolittle, B. Jenkinson, D. Hopkins, M. Ulmer, and W. Tuttle, "Hydropedological investigations with ground penetrating radar (GPR): Estimating water-table depths and local ground-water flow pattern in areas of coarse-textured soils," Geoderma, vol. 131, pp. 317-329, 2006. View at Google Scholar | View at Publisher

[7] G. C. Topp, J. L. Davis, and A. P. Annan, "Electromagnetic determination of soil water content: Measurements in coaxial transmission lines," Water Resources Research, vol. 16, pp. 574-582, 1980. View at Google Scholar | View at Publisher

[8] I. Lunt, S. Hubbard, and Y. Rubin, "Soil moisture content estimation using ground-penetrating radar reflection data," Journal of Hydrology, vol. 307, pp. 254--269, 2005. View at Google Scholar | View at Publisher

[9] B. Schmalz and B. Lennartz, "Analyses of soil water content variations and GPR attribute distributions," Journal of Hydrology, vol. 267, pp. 217- 226, 2002. View at Google Scholar | View at Publisher

[10] J. L. Davis and A. P. Annan, "Ground penetrating radar for high resolution mapping of soil and rock stratigraphy," Geophysical Prospecting, vol. 37, pp. 531-551, 1989.

[11] D. J. Daniels, Ground penetrating radar, 2nd ed. London, UK: The Institute of Electrical Engineers, 2004.

[12] R. A. Freeze and J. A. Cherry, Groundwater. Englewood Cliffs, New Jersey: Prentice Hall, 1979.

[13] O. E. Meinzer, "The occurrence of groundwater in the United States, with a discussion of principles," U.S. Geol. Survey, Water Supply Paper, vol. 489, p. 321, 1923.

[14] R. J. Oosterbaan and H. J. Nijland, Determining the saturated hydraulic conductivity. Chapter 12 in: H.P.Ritzema (Ed.), Drainage principles and applications, 2nd ed. Wageningen, The Netherlands: International Institute for Land Reclamation and Improvement ( ILRI), Publication 16, 1994.

[15] M. S. Alyamani and Z. Sen, "Determination of hydraulic conductivity from grain-size distribution curves," Ground Water, vol. 31 , pp. 551-555, 1993. View at Google Scholar | View at Publisher

[16] T. Masvopo, D. Love, and H. Makurira, "Evaluation of the groundwater potential of the Malala alluvial aquifer, lower Mzingwane River, Zimbabwe," presented at the WaterNet/WARFSA/GWP-SA Symposium, Abstract Vo.9th, Johannesburg, 2008.

[17] A. P. Annan, "Practical processing of GPR data," in Proceedings of the Second Government Workshop on Ground-Penetrating Radar, Columbus, Ohio, 1993.

[18] R. Van Dam and W. Schlager, "Identifying causes of ground-penetrating radar reflections using time-domain reflectometry and sedimentological analyses," Sedimentology, vol. 47, pp. 435-449, 2000.

[19] L. B. Conyers, Ground penetrating radar for archaeology. Lanham: AltaMira Press, 2004.

[20] D. A. Morris and A. I. Johnson, "Summary of hydrologic and physical properties of rock and soil materials as analyzed by the hydrologic laboratory of the U.S. Geological survey. U.S. Geological Survey Water-Supply Paper No.1839-D," p. 42 , 1967.

[21] M. Nord, Sand rivers of Botswana: Phase 2; Department of Water Affairs, Government of Botswana, 1985.

[22] R. D. Holtz and W. D. Kovacs, An introduction to geotechnical engineering: Prentice Hall, 1981. 